
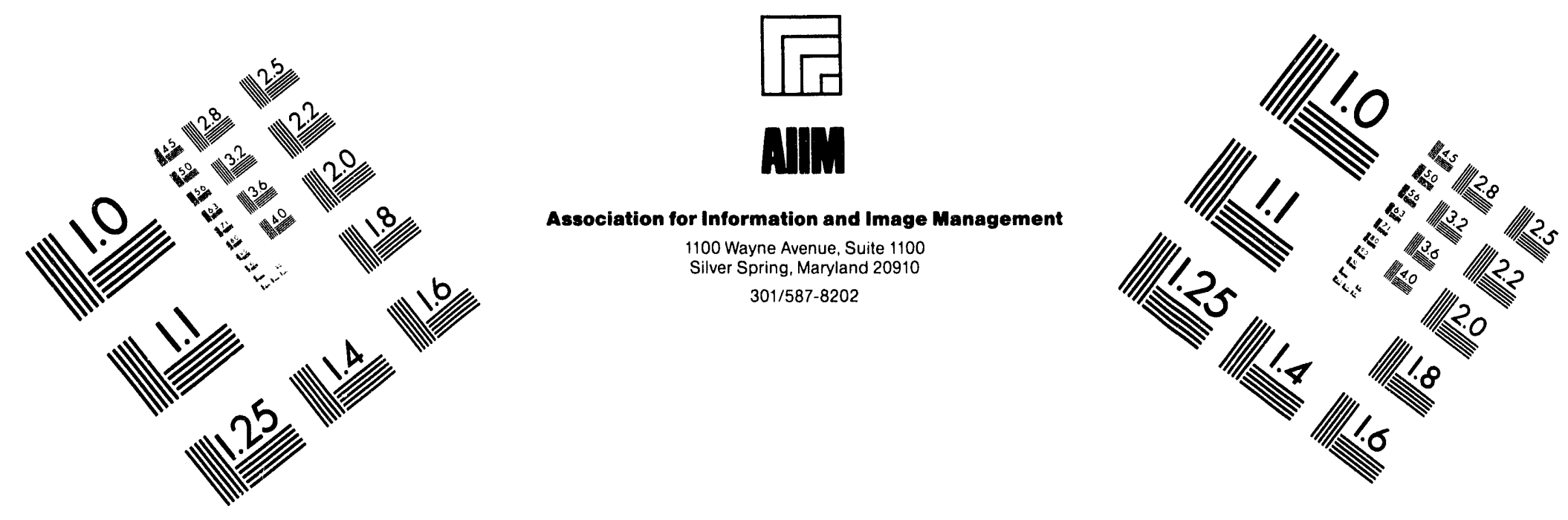

\title{
Centimeter
}

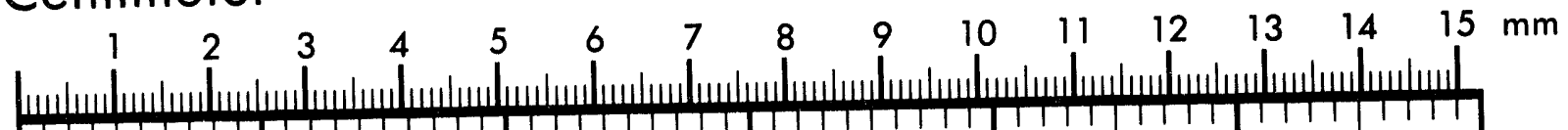

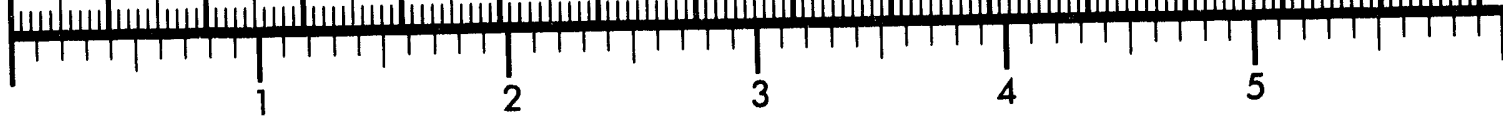
Inches

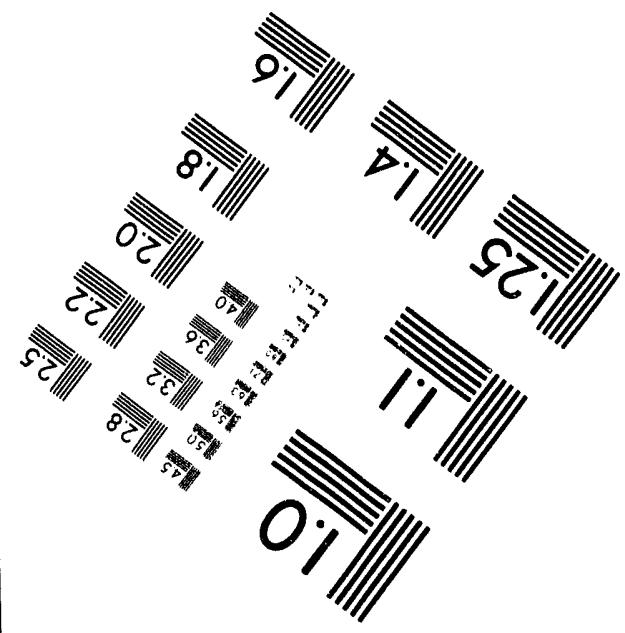

MANUFACTURED TO AIIM STANDARDS

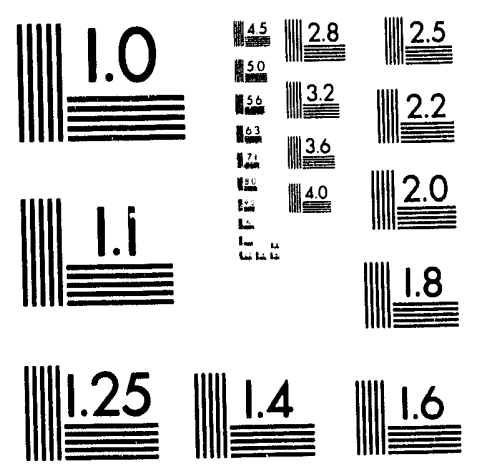

$$
\text { BY APPLIED IMAGE, INC. }
$$

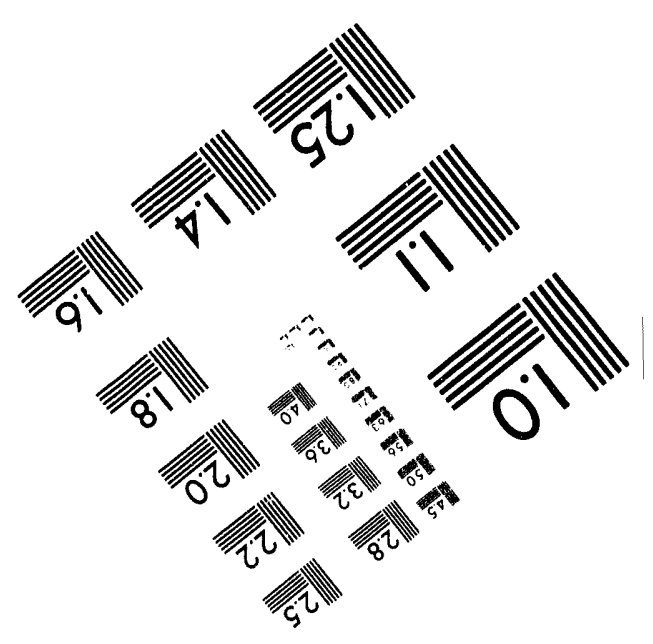



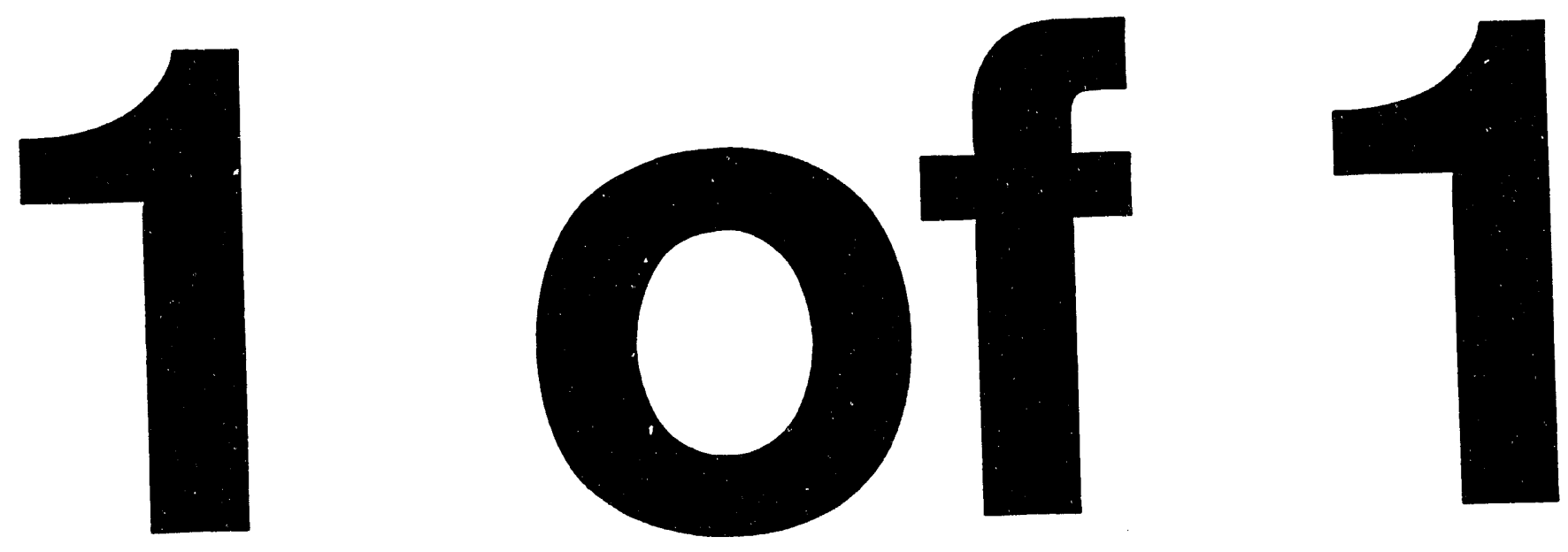


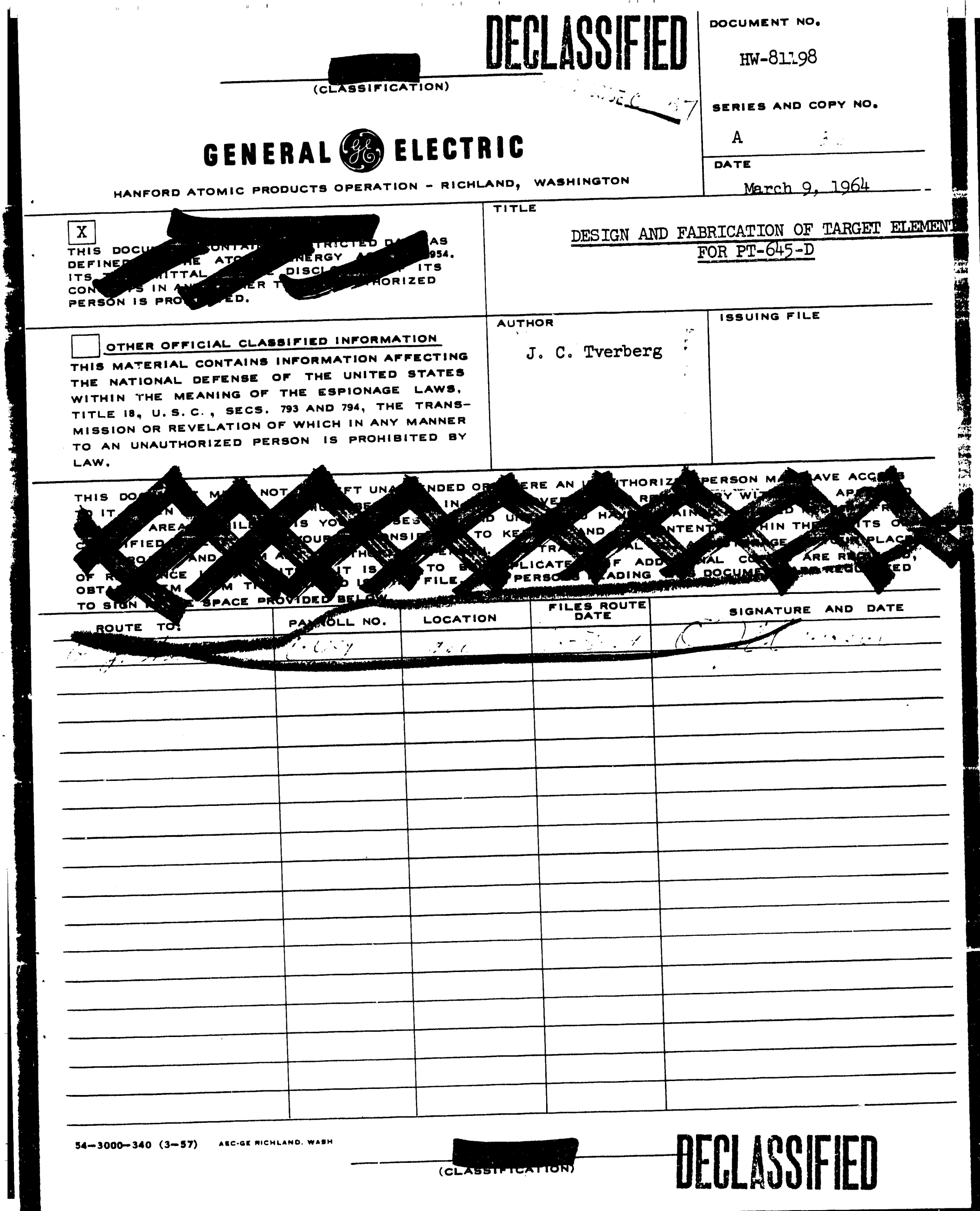


This document consists of

This document classifled by:

i pages.

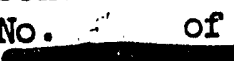

C

DESIGN AND FABRICATION OF TARGET FHTMMENTS

FOR PT-645-D

By

J. C. Tverberg

Metal Fabrication Development Metallurgy Development Operation

Reactor and Fuels Iaboratory

Hanford Laboratories

March 9, 1964

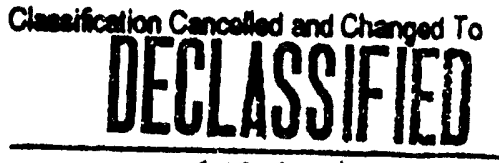

By Authoily of SE Gydesen, $C G-P R-2,4-6-94$ By DKttanson $417-94$

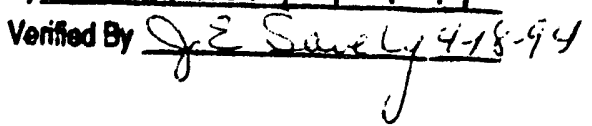

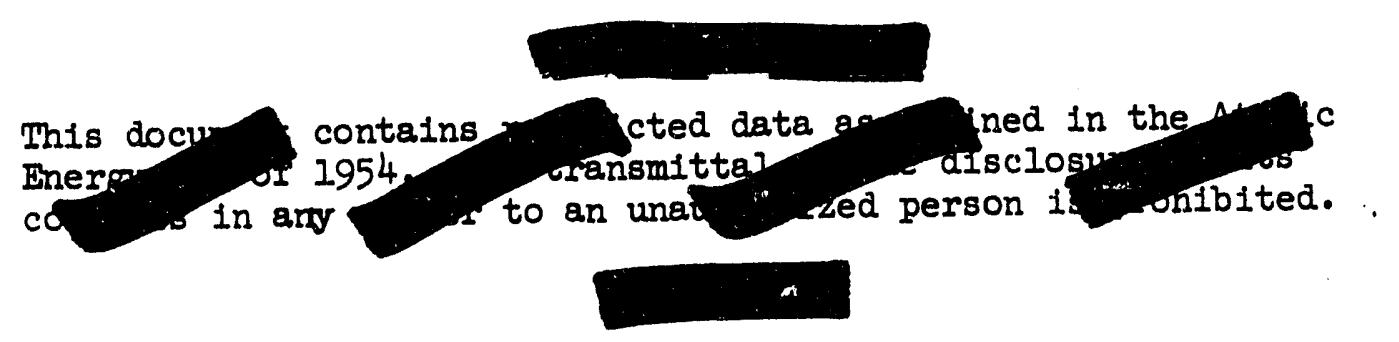

MASTER

DECLISSIFIED

$g 70$ 
1. F. W. Albaugh

2. T. W. Ambrose

3. P. A. Ard

4. J. A. Ayres

5. J. M. B1rd

6. J. J. Cadwell

7. D. H. Curtiss

8. T. I. Deobald

9. R. J. Dickeman

10. R. I. DiIIon

11. T. W. Evans

12. V. I. Gelezuns,

13. J. W. Goffard

14. 0. H. Greager

15. W. A. Hendrickson

16. W. K. Kratzer
17. G. A. Last

18. M. C. Leverett

19. C. G. Lewis

20. Milton Iewis

21. L. M. Loeb

22. J. E. Minor

23. T. D. Naylor

24. Robert Neidner

25. J. W. N1ckolaus

26. J. W. Riches

27. C. H. Shaw

28. R. K. Studer

29. J. C. Tverberg

30. O. J. Wick

31. Record Center

32. 300 Area Files 


\section{DESIGN AND FABRICATION OF TARGET FHEMENIS FOR PT-645-D}

\section{J. C. Trerberg}

March 9, 1964

ABSTRACT

Target elements were designed and built to fit into $1.25 \% \mathrm{U}^{235}$ driver elements. These targets had an aluminum - $0.583 \%$ lithium alloy core enriched to $63.5 \%$ in $\mathrm{II}^{6}$. The targets had a coextruded aluminum jacket as a tritium barrler and a Zircaloy jacket as a corrosion barrier to the $300 \mathrm{C}$ reactor water.

\section{INIRODUCTION}

A malt1-product program has been proposed for N-Reactor, the goal of which is to produce low cost weapons grade plutonium with steam and tritium as saleable (1)

by-products. The feasibility of this concept will be shown in two tests, the first of which is a one column test in KE, the second will be a 36 tube demonstration loading in $N$-Reactor to be underway by October 1964. Both tests will use a $1.25 \%$ enriched uranium driver in the form of a single tube with the target rod placed in the center. The 36 tube test w11l be arranged in a $6 \times 6$ array in Which the four central tubes will provide physics data on yield and control problems. (3)

The target elements described in this report are part of the precursor irradiation test. This test, PT-645-D, w1Il be irradiated in KER-3. (4) The driver elements, produced by N-Fuels Engineering, NRD, are 2.292 inches OD by 1.441 inches ID, with a 0.035 inch Zircaloy clad on the OD and 0.025 inch on the $I D$. The driver elements are $26.10 \pm 0.06$ inches in length with end closures brazed and welded in place.

The target elements were specifled to have a fertile 1sotopic content of 0.272 grams of $\mathrm{Li}^{6}$ per foot of element, assuming an infinite length. Allowance for end caps, expansion vold and lit-up clearances between adjacent rods increased this value somewhat. The target element length was to be less than the drivers, so a length of $26.020 \pm 0.040$ was chosen. DFP 
Based on previous experience a decision was made to coextrude aluminum over the core, weld end caps in position, then to clad in Zircaloy. Target dimensions were chosen on the basis of available PRTR Zircaloy tubing, thus the present elements do not necessarily represent the optimum design.

This report gives the design basis, the dimensions and composition and the mode of fabrication for these elements.

\section{DESIGN AND FABRICATION}

\section{Composition}

Enriched Ilthium was allowed in this test, so that a single phase alloy core would be obtained. For the finite lengths necessary in this test, the calculated $\mathrm{Li}^{6}$ content becomes $0.286 \mathrm{gm} / \mathrm{ft}$. Enriched lithium-aluminum scrap containing 1.99\% Ii enriched to $63.5 \% \mathrm{II}^{6}$ was alloyed with 1100 aluminum to make the final alloy of $0.559 \%$ lithium.

\section{Fabrication}

\section{Melting}

The alloy was induction melted in an argon atmosphere. Melting crucibles were commercial "Dixon" clay-graphlte cruclbles, coated with a zirconium oxideacetone slurry. Zirconla was the only coating that would withstand the corrosive attack of lithium-containing alloys. It was necessary to place the aluminum on the bottom of the crucible where melting occurred first and to place the aluminum-lithium master alloy on the top so that the lithium alloy would be diluted before contacting the graphite. Lithium has a very great affinity for carbon according to the reaction

$$
2 \mathrm{LI}+2 \mathrm{C} \longrightarrow \mathrm{Li}_{2} \mathrm{C}_{2} \cdot
$$

Even with the mold coating this reaction took place to a limited degree as Indicated by the acrid smell of acetylene when the furnace was opened. Acetylene was formed by the reaction of IIthium carbide with the moisture in the air 
according to the reaction

$$
\mathrm{H}_{2} \mathrm{O}+\mathrm{II}_{2} \mathrm{C}_{2} \longrightarrow 2 \mathrm{IHOH}+\mathrm{C}_{2} \mathrm{H}_{2} \text {. }
$$

During melting the crucible was heated to $625 \mathrm{C}$ at a pressure of $10^{-2}$ Torr at which time the system was backfilled with argon to a pressure of 675 Torr. The melt was heated to $700 \mathrm{C}$ and held for five minutes, then poured into watercooled graphite molds. To prevent piping of the ingot the mold was continuously vibrated and hot topped until completely solidified.

\section{Pre-Extrusion}

The cast ingot was machined into a right cylinder 4.00 inches diameter, II $\frac{1}{2}$ inches long, coated with Fisk's 604 lubricant and extruded at room temperature into a billet $2 \frac{1}{4}$ inches diameter. The reduction ratio was $3.30: 1$. Equipment limitations dictated this reduction, a still higher reduction in area would have been preferrable. Cold extrusion was used to induce the maximum amount work hardening in the billet.

Earlier coextrusion tests showed that a work hardened billet would produce no bonding between the core and clad, and that an annealed core would result in bonding. Various billet surface preparations were also tried but all resulted in some degree of bonding. As a result we chose the work hardened condition for our coextrusion billet assembly.

\section{Coextrusion}

The core billet was cut into $6 \frac{1}{4}$ inch lengths, then machined into right cylinders, 1.915 inches diameter by 5.75 inches long. These were placed into 1100 aluminum billet cans, the dimensions adjusted to give a 0.032 inch jacket on the final extrusion. Flgure $I$ shows a dimensioned cross-sectional drawing. These billets were argon arc welded in air, vapor blasted and imersion copper plated in a $\mathrm{HF}-\mathrm{CuSO}_{4}$ plating bath to a uniform visual copper plate. The billets were then heated in an air furnace to $400 \mathrm{C}$ to oxidize the copper, then cooled to

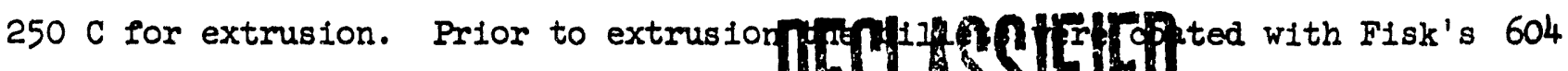
DELESTFF 
lubricant and pushed from a cold container through a cold die at a ram speed of 24 inches per minute. The extrusion ratio was $20.25: 1$, the die exit diameter 0.503 inch. The extrusions had a very smooth surface typical of this lubricant.

Figure 2 shows a cross sectional view of the coextrusion. The cladding was completely unbonded on each specimen as specified.

\section{Target Core Fabrication}

Wlements 25.35 inches long were cut from the coextrusions, and the fertile core was counterbored 0.185 inches on each end. After removal of the extrusion lubricant, end caps were welded into position with a hand held argon arc torch. Cores were then completely vapor blasted and the welds were X-rayed.

\section{Final Assembly}

The Zircaloy containment can was made from PRTR fuel tubing, 0.565 inch OD by 0.505 inch ID cut into 26.00 inch lengths. After a bright etch, uncollapsed N-Inner fuel element supports were welded at $120^{\circ}$ intervals in three positions on the tube. Because of slight dimples under each weld nugget a 0.505 inch diameter plug was drawn through the tube.

The target cores were coated with dry flake graphite and then slid into the tube. Without graphite it was impossible to assemble the target elements. After assembly the cores were centered in the target can then placed in a vacuum glove box. The chamber was evacuated, then backfilled with helium. End caps were set in place with a positioning tool and welded in place. The completed element is shown in detail in Figure 3 .

\section{Final Inspection}

Three modes of inspection were used to prove the integrity of the target elements. The first method was a helium leak test with a helium sensitive mass spectrometer. Each element was placed in a vacuum chamber, evacuated, and the residual gas checked for hellum. 
The second method was to X-ray the weld zone at $40^{\circ}$ intervals, and to $100 \mathrm{k}$ for evidence of reld stringers or volds.

The third test was to autoclave in $300 \mathrm{C}$ water at $1500 \mathrm{psi}$ for 72 hours to test weld quality.

Elements that passed these tests had iron shoes, placed over the Zircaloy supports and were then turned over to N-Fuels Engineering for final assembly with the driver tube.

\section{Design Criteria}

Many of the design details were adopted from those used by V. L. Gelezunas in his capsule irradiation tests.

The desirability of a single phase alloy has been discussed in detail by (5)

Gelezunas. Experience has shown that about $2 \%$ lithium is the maximum that can be held in an aluminum solid solution. The desirability of a single phase alloy comes from a very fine distribution of lithium in an aluminum solid solution which prevents macroscopic transport of lithium compounds along grain boundaries. The main disadvantage of a single phase alloy is the low $\mathrm{Li}^{6}$ concentration, which, for practical and economical production of tritium requires the use of lithium enriched: in the fertile isotope $\mathrm{Li}^{6}$. At $300 \mathrm{C}$ swelling in single phase alloys becomes a problem only at exposures greater than $30 \mathrm{GVR}$. Since this exposure is twice the anticipated Hanford exposure no problems are anticipated in the use of a single phase, enriched lithium target.

The capsule experiments were built with a center hole filled with helium to accommodate any swelling. Irradiation data, however, showed that there was little or no change in the hole dimension at exposures up to $30 \mathrm{GVR}$. On this basis the center hole was eliminated, and a coextruded aluminum jacket was used to provide the tritium diffusion barrier.

The length of the target elements was calculated to prevent end loading on the Zircaloy end caps, taking into account the coefficients of expansion of

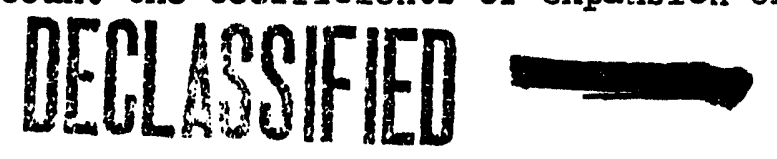


aluminum and Zircaloy. Coefficients of thermal expansion of $24.5 \times 10^{-6}$ in $/{ }^{\circ} \mathrm{C}$ for aluminum and $5 \times 10^{-6}$ in $/{ }^{\circ} \mathrm{C}$ for Zircaloy were used. The calculations are as follows:

For aluminum: $25.35^{\prime \prime} \times 24.5 \times 10^{-6}{ }_{\text {in }} /{ }^{\circ} \mathrm{C} \times 300 \mathrm{C}=0.186 \mathrm{in}$.

For Zircaloy: $\left(-26.00^{\prime \prime} \times 5 \times 10^{-6} \mathrm{in} /{ }^{\circ} \mathrm{C} \times 300 \mathrm{C}=\frac{-0.039}{0.147} \mathrm{in}\right.$.

The actual longitudinal gap was 0.190 inch.

The space within the Zircaloy can was filled with helium to provide a heat transfer medium. At an average radial gap of 0.002 inch at room temperature the target core would contact the Zircaloy can wall at 155 C. Beyond this temperature, the volumetric expansion would be taken up by expansion into the end void.

Figure 4 gives a plot of the radial expansion of a 0.504 inch diameter target rod as a function of temperature. The major question which arises at this point is the temperature at which the helium pressure increases sufficiently to cause deformation of the Zircaloy. Assuming that helium acts as a perfect gas and applying the 1deal gas law we obtain the curve shown in Figure 6, that of target temperature as a function of internal helium pressure. It is seen that at $300 \mathrm{C}$, the design operation temperature, the internal pressure is only $85 \mathrm{psi}$. The temperature at which the target rod fills the allowed space is $367 \mathrm{C}$. However, because of the weid-recess in the end caps the pressure is only 175 psi. A temperature of $445 \mathrm{C}$ is required to reach $1300 \mathrm{psi}$, loop operation pressure and a temperature of $447 \mathrm{C}$ is necessary to completely close all gas expansion voids and cause the pressure to increase to bursting levels.

Pre-welding the supports to the Zircaloy can was necessitated by earlier results from the fabrication of capsules for Gelezunas. He noted a weld nugget under each weld tab extending into the aluminum, thus making an easy diffusion path for tritium from the core into the Zircaloy can.

The supports used were uncollapsed $\mathrm{N}$-inner supports with the thickness increased to 0.042 inch. Testing is currently underway by Fuels Design to optimize the support design. 


\section{TARGET HUEMENT DATA}

\section{Composition}

In almost every case the lithium content was higher than calculated for the melt make-up. This indicates that the Savannah River master alloy analyses were possibly in error. Existing methods of lithium analysis leave much to be desired, the best being flame photometry. If the standards are correct then it is possible to obtain a maximum accuracy of $\pm 3 \%$ of the determined value. Spectrophotometry is being rapidly improved, so it is possible that the average accuracy will soon equal the maximum accuracy. Density measurements were also made and it is proposed that density be used for control during fabrication rather than chemical analyses.

Specimens were submitted for mass spectrographic determination of $\mathrm{Li}^{6}$, however, these results will not be available for several months. Table I gives the composition and density data for each element. The average lithium content was $0.583 \%$ Li with an average density of $2.662 \mathrm{gm} / \mathrm{cc}$ for a calculated $\mathrm{Li}{ }^{6}$ distribution of $0.299 \mathrm{gm} / \mathrm{ft}$. This represents a $4.35 \%$ increase over design levels of $.559 \% \mathrm{LI}$ and $0.286 \mathrm{gm} \mathrm{Li} / \mathrm{ft}$.

Spectrographic analysis of the impurity elements indicated that only iron occurred to any great extent in the cores. Minor impurities were vanadium, silicon, nickel, manganese, magnesium, copper and chromium. A chemical analysis indicated that $0.055 \%$ iron, $0.057 \%$ copper, $0.010 \%$ nickel and $0.030 \%$ manganese were present.

The aluminum cladding showed copper and iron as the major impurities, each around $0.15 \%$. The other trace elements were about the same as for the core alloys.

\section{Extrusion Results}

The extmided elements conformed very closely to the design diameter of $0.504 \mathrm{inch}$, in that the average diameter was 0.5037 inch. The maximum ovality 


\section{TABLE I}

Composition and Density Values for Target Cores

\begin{tabular}{|c|c|c|c|c|}
\hline $\begin{array}{c}\text { Target } \\
\text { Core } \\
\end{array}$ & $\begin{array}{l}\text { Sample } \\
\text { Number }\end{array}$ & $\begin{array}{c}\text { of II } \\
\text { By WeIght }\end{array}$ & $\begin{array}{c}\text { Density } \\
\mathrm{gm} / \mathrm{cc}\end{array}$ & $\begin{array}{l}\mathrm{LI}^{6} \text { Distribution } \\
(\mathrm{calc}) \mathrm{gmi} 1^{6} / \mathrm{ft}\end{array}$ \\
\hline A & $I A I$ & 0.586 & 2.660 & 0.299 \\
\hline B & IA2 & 0.578 & 2.658 & 0.296 \\
\hline C & $1 \mathrm{~A} 3$ & 0.568 & 2.653 & 0.290 \\
\hline G & $1 \mathrm{Cl}$ & 0.587 & 2.657 & 0.309 \\
\hline $\mathrm{J}$ & 1DI & 0.594 & 2.667 & 0.304 \\
\hline $\mathrm{K}$ & IDR & 0.601 & 2.664 & 0.307 \\
\hline$L^{*}$ & 1D3 & 0.594 & 2.671 & 0.304 \\
\hline $\mathrm{N}$ & $2 A 2$ & 0.581 & 2.662 & 0.297 \\
\hline $\mathrm{P}$ & $2 \mathrm{BI}$ & 0.584 & 2.669 & 0.299 \\
\hline$Q$ & $2 B 2$ & 0.569 & 2.661 & 0.291 \\
\hline $\mathrm{R}$ & $2 B 3$ & 0.586 & 2.666 & 0.299 \\
\hline $\mathrm{S}$ & $2 \mathrm{Cl}$ & 0.583 & 2.666 & 0.298 \\
\hline $\mathbf{T}$ & $2 C 2$ & 0.586 & 2.660 & 0.299 \\
\hline $\mathrm{U}$ & $2 C 3$ & 0.587 & 2.663 & 0.300 \\
\hline $\mathrm{V}$ & $2 \mathrm{DI}$ & 0.586 & 2.658 & 0.299 \\
\hline $\mathrm{W}$ & 2DR & 0.569 & 2.658 & 0.291 \\
\hline $\mathrm{x}$ & 2D3 & $\underline{0.578}$ & 2.667 & 0.296 \\
\hline Average & & 0.583 & 2.662 & 0.299 \\
\hline
\end{tabular}

*Standard Element for Bulk Density 
was 0.0005 inch with an average of 0.0002 inch. The cladding was, in general, very uniform with an average thickness of 0.0334 inch. Some variation was observed, but the maximum was only 0.0020 inch, with an average of 0.0007 inch. The only place where bonding was noted on the peel test specimens was at the nose end of each extrusion. Care was taken not to take any core close to the lead end of the extrusion. Table II presents the coextrusion data on each element.

\section{Inspection}

Examination of the weld X-rays showed volds and oxide and tungsten inclusions as the main faults. Unaccepted elements were rewelded where possible and reprocessed until a good X-ray was obtained. Those elements which coula not be reclaimed after the second reweld were scrapped. After enclosure in Zircaloy neither the helium leak test nor the X-ray examination showed any sign of failure. Ilkewise, the autoclave cycle showed that all welds were contamination free.

\section{Final Dimensions}

Prior to release the elements were measured and the bulk density determined. These data are given in Table III. A photograph of these elements is shown in Figure 5 .

\section{CONCLUSIONS}

A method of fabrication for reactor quality target elements has been developed and the delivery scheduie met. These elements have a composition of $0.583 \% \mathrm{Li}$, enriched to $63.5 \mathrm{Li}^{6}$, for a $\mathrm{Li}^{6}$ distribution of $0.299 \mathrm{gm} / \mathrm{ft}$. The cores were clad by coextrusion with an aluminum jacket and welded end plugs for a tritium containment can, then placed in a Zircaloy can for corrosion resistance to the high temperature water. These elements provide the fabrication basis for the larger 36 tube loading to be irradiated starting in October 1964. 


\section{TABLE II}

Co-Extmusion Data on Parget Elements

\begin{tabular}{|c|c|c|c|c|c|c|c|}
\hline $\begin{array}{c}\text { Target } \\
\text { Core }\end{array}$ & $\begin{array}{l}\text { Sample } \\
\text { Number }\end{array}$ & $\begin{array}{c}\text { Diameter } \\
\text { Inches }\end{array}$ & $\begin{array}{r}\text { Ovality } \\
\text { (Ave.) }\end{array}$ & $\begin{array}{l}\text { Cladding } \\
\text { Inches }\end{array}$ & $\begin{array}{c}\text { Var. } \\
\text { (Ave.) }\end{array}$ & $\begin{array}{l}\text { Core } \\
\text { Dia. }\end{array}$ & $\begin{array}{c}\text { Bonded } \\
? \\
\end{array}$ \\
\hline A & $I A I$ & .5040 & .0005 & .0332 & .0005 & .429 & No \\
\hline B & $1 \mathrm{~A} 2$ & .5035 & .0005 & .0330 & .0000 & .442 & No \\
\hline$C$ & $2 \mathrm{A3}$ & .5033 & .0002 & .0330 & .0005 & .440 & No \\
\hline G & $1 \mathrm{Cl}$ & .5017 & .0002 & .0295 & .0008 & .444 & No \\
\hline $\mathrm{J}$ & $1 D 1$ & .5035 & .0000 & .0330 & .0000 & .439 & Some \\
\hline $\mathrm{K}$ & IDR & .5050 & .0000 & .0325 & .0005 & .439 & No \\
\hline$L^{*}$ & 1D3 & .5057 & .0002 & .03 .37 & .0005 & .439 & No \\
\hline $\mathrm{N}$ & $2 A 2$ & .5045 & .0005 & $\therefore 0320$ & .0001 & .441 & No \\
\hline$P$ & $2 B 1$ & .5033 & .0002 & .0330 & .0000 & .441 & Some \\
\hline$Q$ & $2 B 2$ & .5030 & .0000 & .0350 & .0010 & .436 & No \\
\hline $\mathbf{R}$ & $2 B 3$ & .5035 & .0000 & .0310 & .0010 & .447 & No \\
\hline$S$ & $2 \mathrm{Cl}$ & .5035 & .0005 & .0371 & .0020 & .430 & No \\
\hline$T$ & $2 \mathrm{C2}$ & .5040 & .0000 & .0321 & .0005 & .430 & No \\
\hline U & $2 C 3$ & .5033 & .0002 & .0335 & .0005 & .437 & No \\
\hline V & $2 D 1$ & .5035 & .0000 & .0390 & .0012 & .437 & No \\
\hline W & 2DR & .5037 & .0002 & .0339 & .0007 & .436 & No \\
\hline $\mathrm{X}$ & 2D3 & .5042 & .0002 & .0330 & .0001 & .439 & No \\
\hline Average & & .5037 & .0002 & .03 .34 & .0007 & .438 & \\
\hline
\end{tabular}

*Standard Element for Bulk Density 
Final Dimensions and Bulk Densities for Target Elements

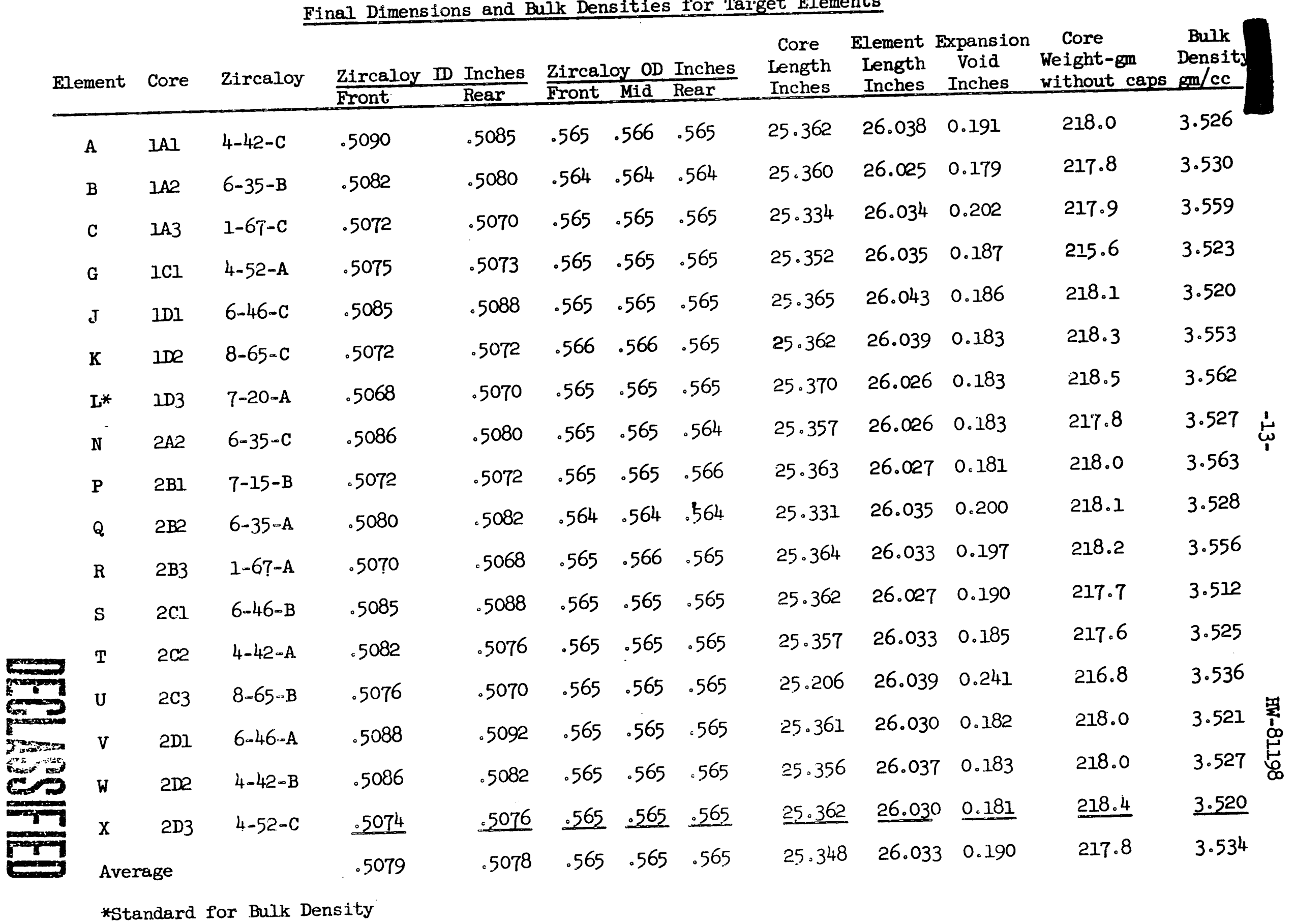




\section{BIBLIOGRAPEY}

1. Staff, R\&E, NRD, "A Program for Multi-Product Operation of the N-Reactor," HW-78864, Sept.9, 1963. (Secret)

2. R. I. Dickeman, "Co-Product Program--N-Reactor," HW-79289, Oct. 17, 1963. (Conf.)

3. T. W. Evans, "Responsibilities for Fabrication of Co-Producer Test Elements," Undocumented, Dec.6, 1963. (Conf。)

4. T. W. Evans, "N-Reactor Fuel Testing Program in the KER Loops," Undocumented, Nov. 11, 1963. (Conf.)

5. V. I. Gelezunas, "The Production of Tritium at Intermediate Temperatures by Means of the $\mathrm{LI}^{6}(n, \alpha) \mathrm{H}^{3}$ Reaction, "HW-76297, Jan. 21, 1963. (Secret) 


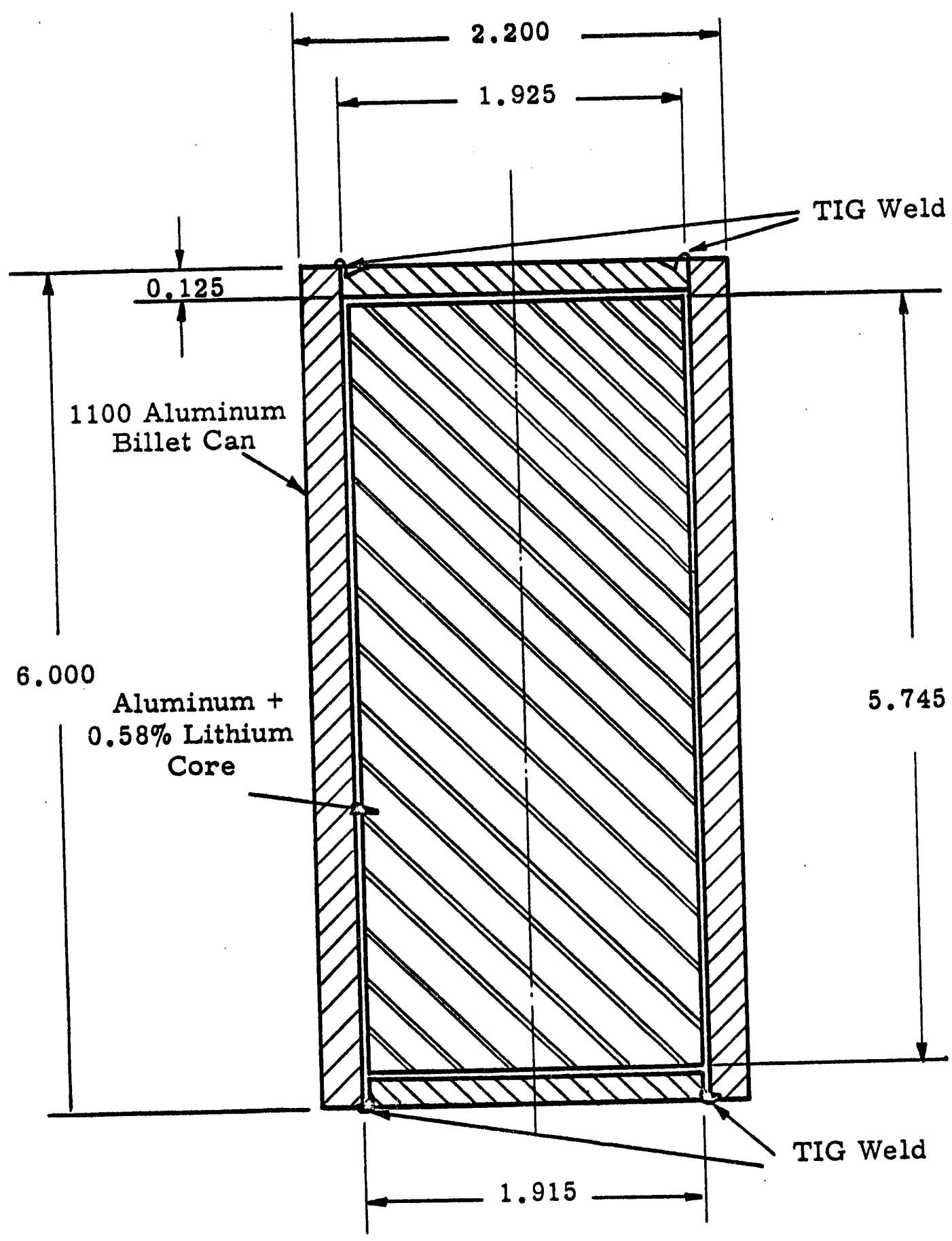

FIGURE 1

Co-extrusion Billet Details 


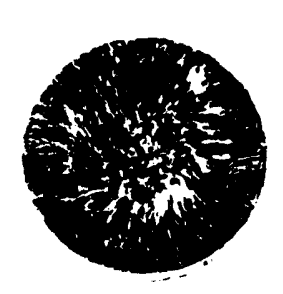

FIGURE 2

Cross Section of Co-extruded Target Core. The Core is an Aluminum $0.583 \%$ Lithium Alloy, the 0.032 inch Cladding is 1100 Aluminum. Reduction Ratio 20:1 at $250 \mathrm{C}^{\prime} \quad \mathrm{X}$ 


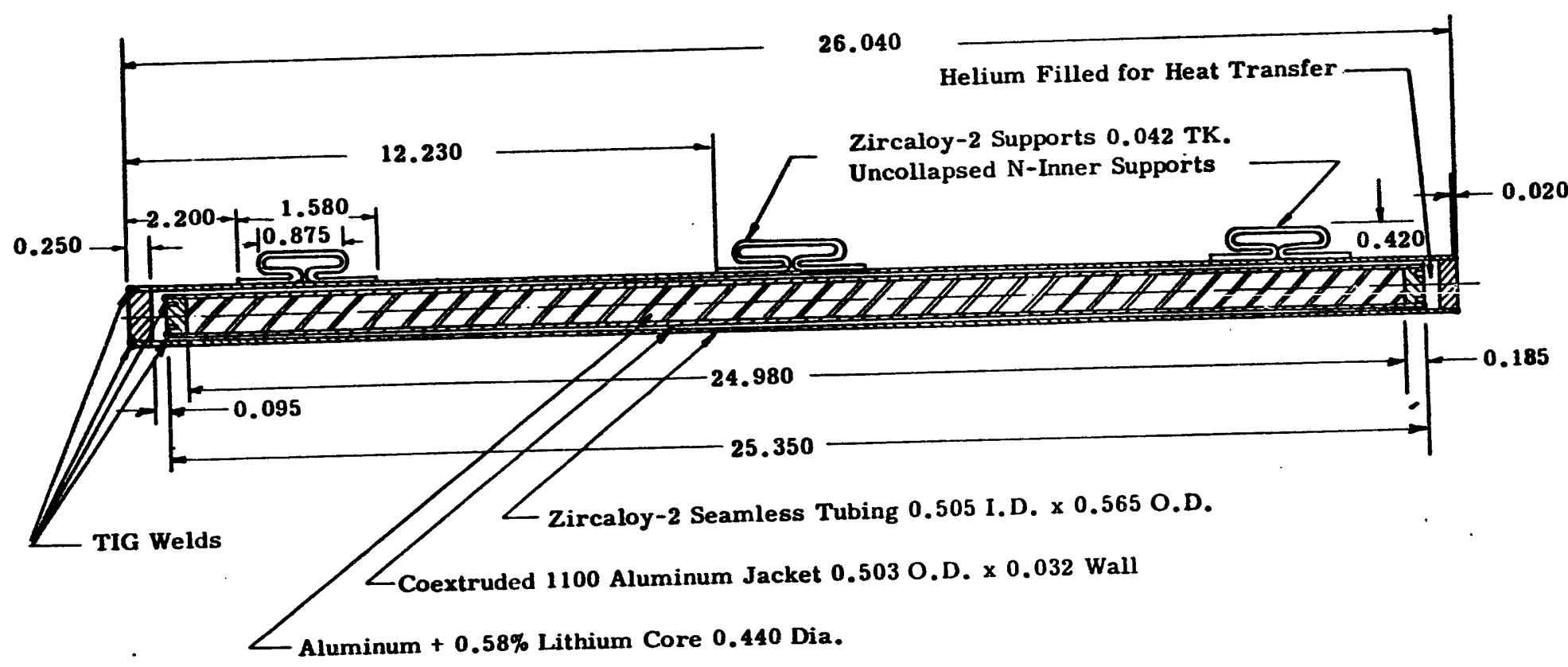

\section{FIGURE 3}

Target Element Details 


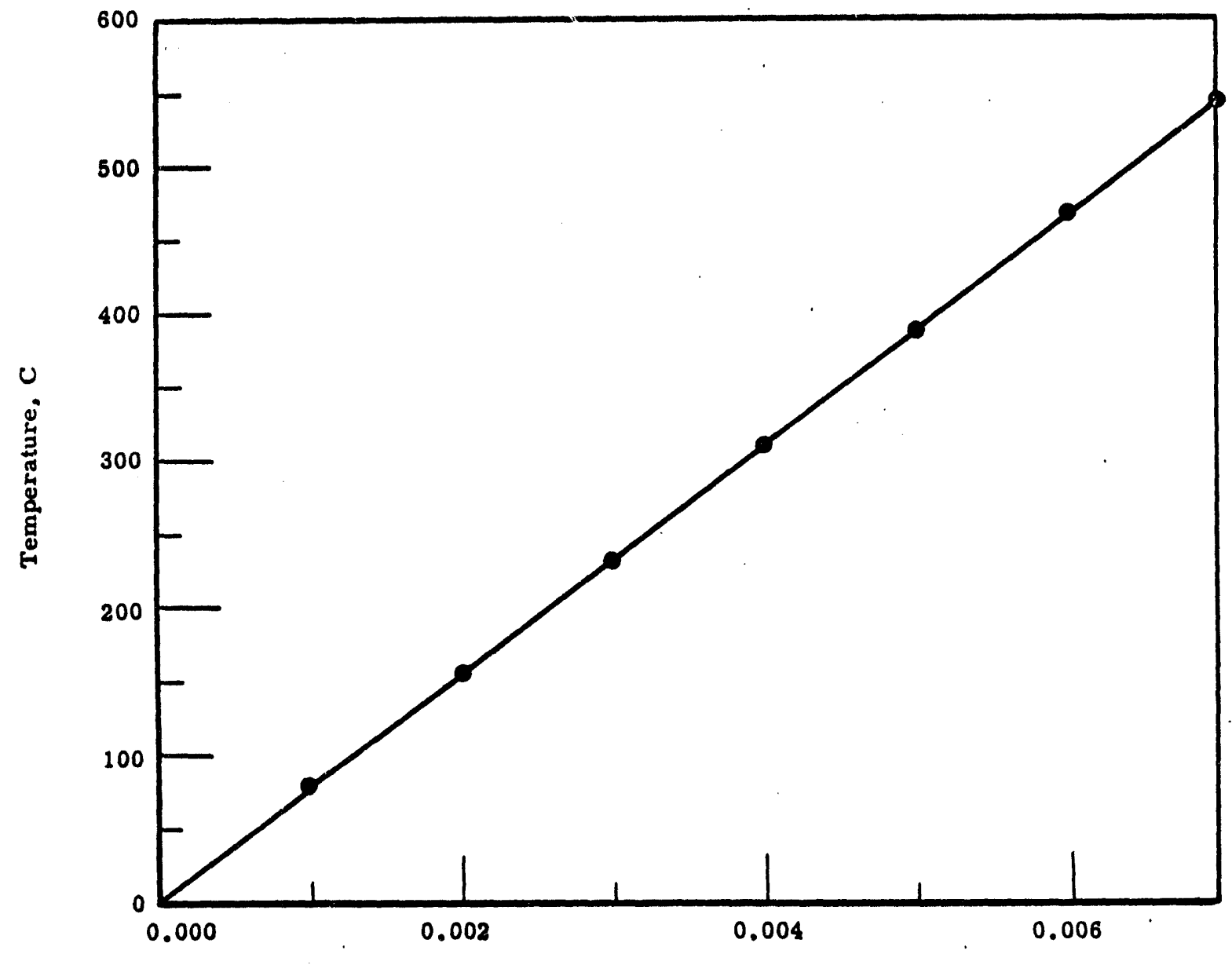

Radial Expansion (10-3 inch) on 0.504 inch Diameter Rod

\section{FIGURE 4}

Radial Expansion of Target Cores as a Function of Core Temperature 


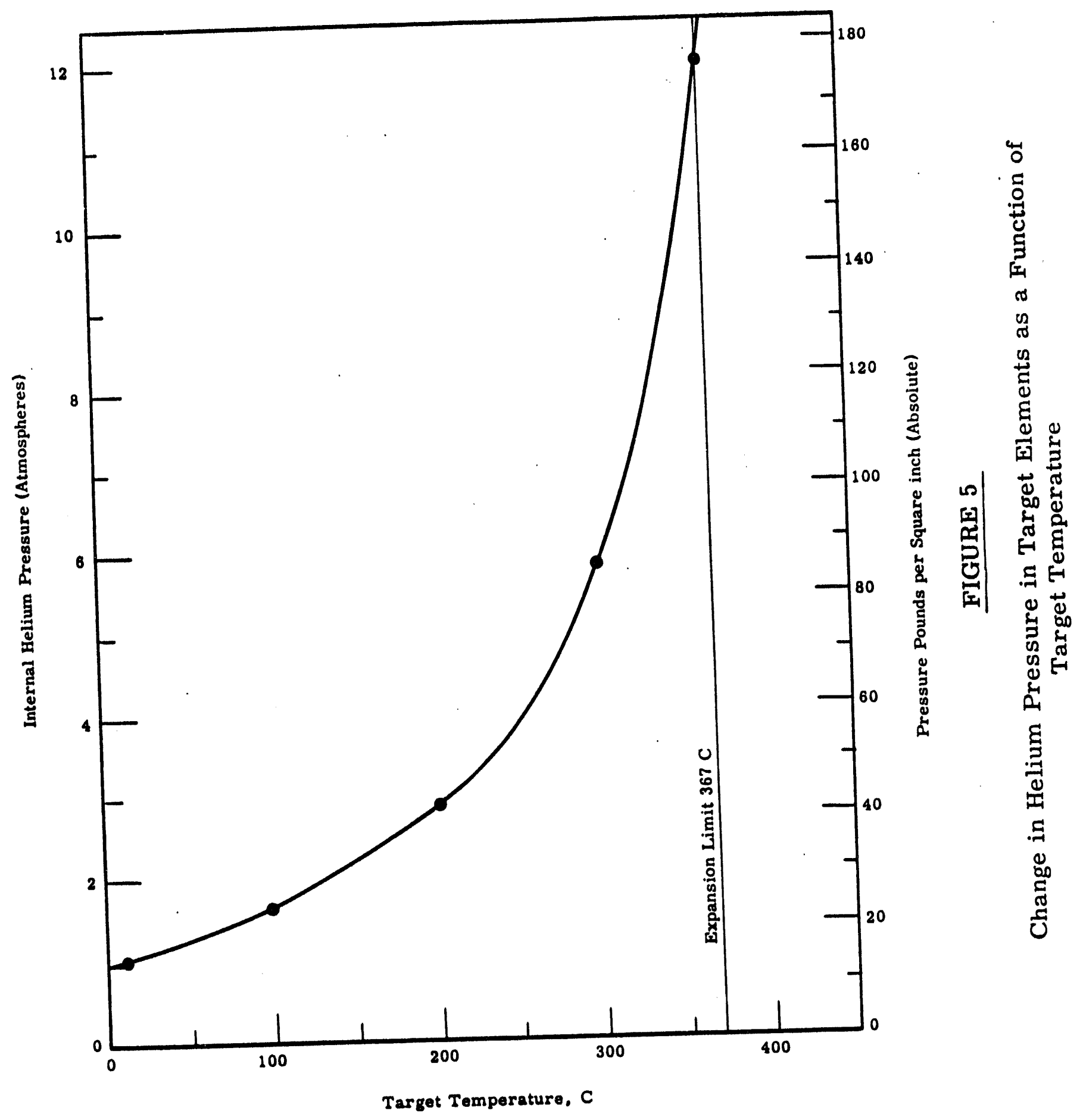

AEC-es nichlane, wash 
001115977370

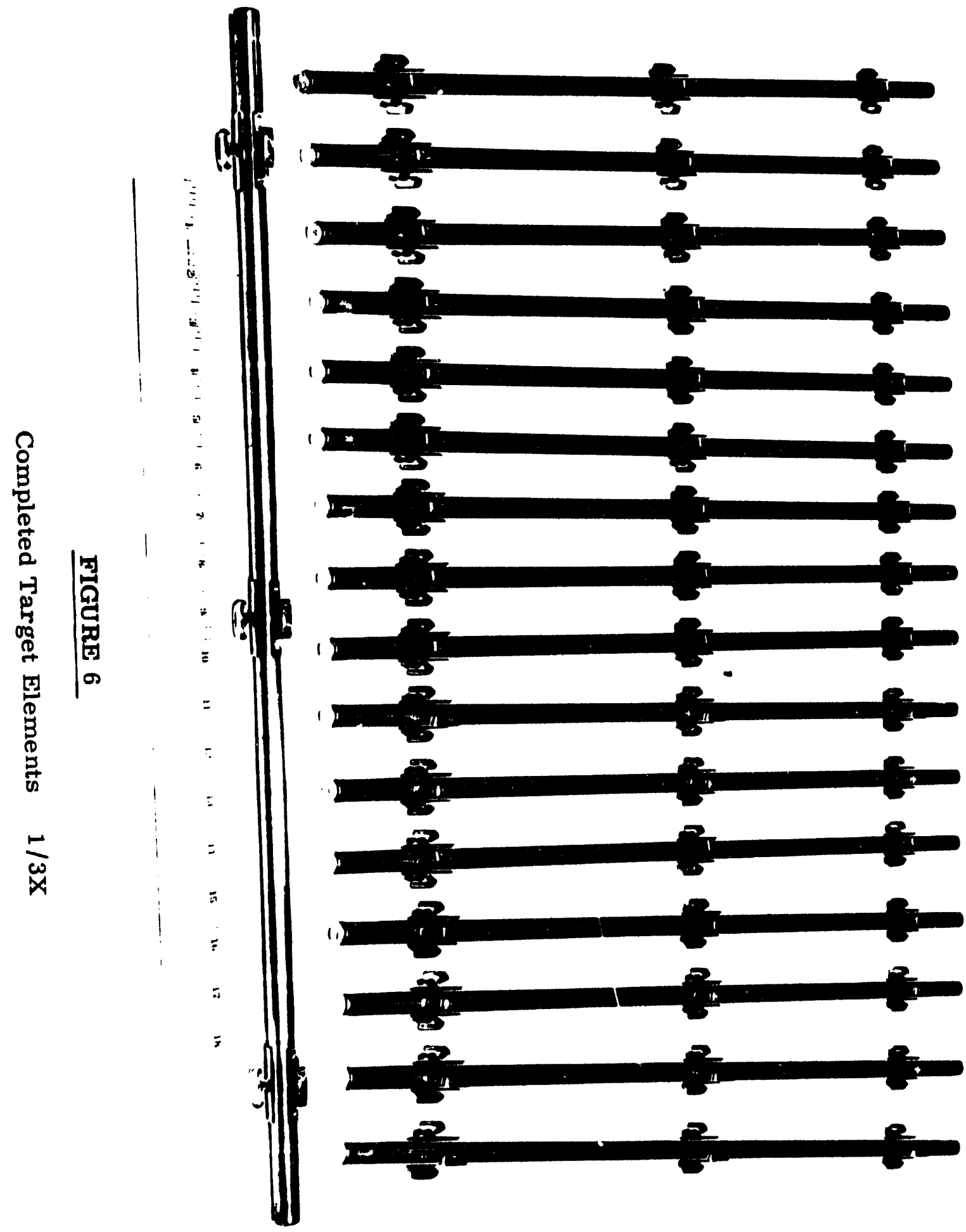

86 โ $โ 8-M H$

$-0 z-$

[0]1패S57930 

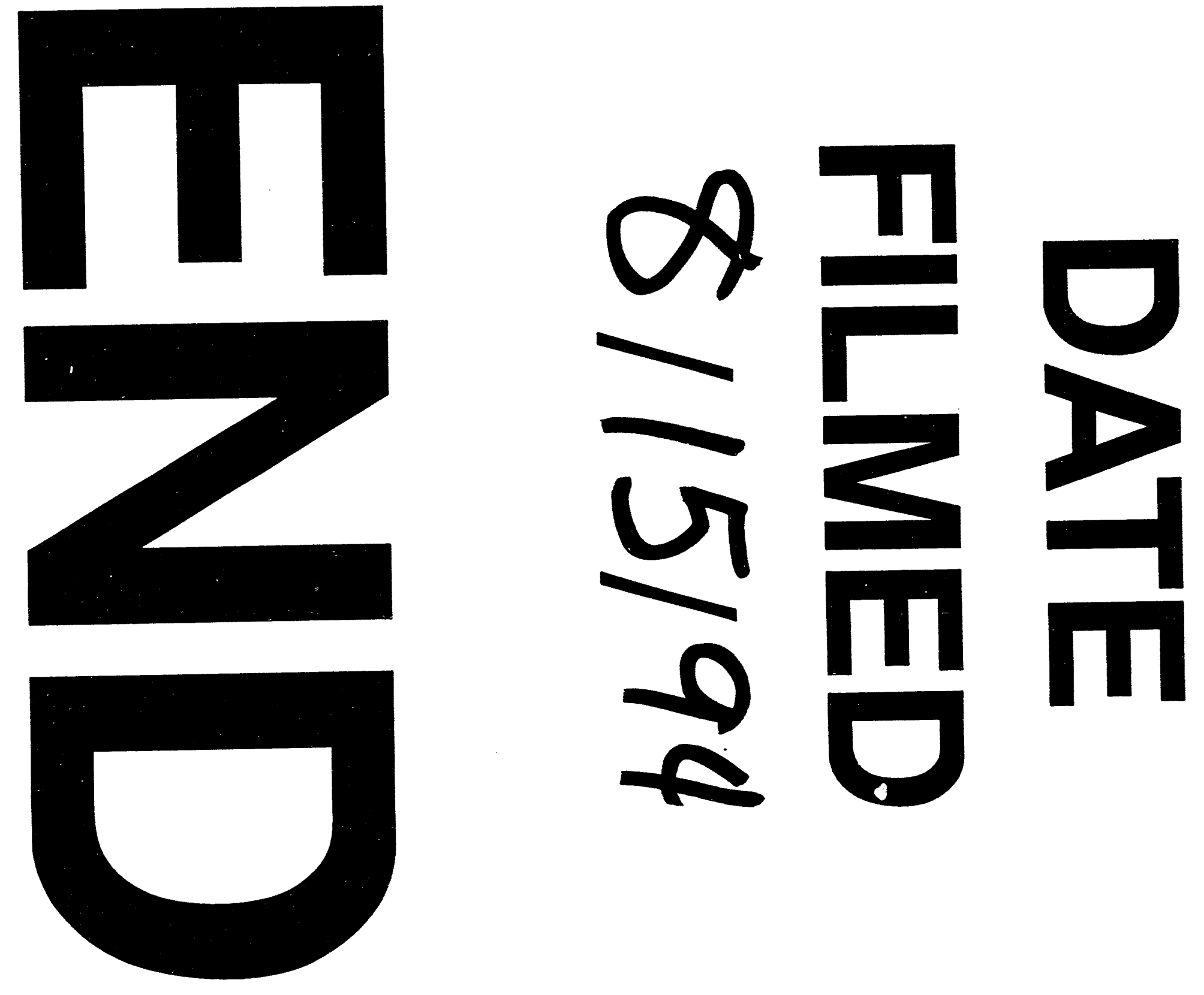
